\title{
The Impact Of Used Imported Fridges, $\quad$ Freezers And Air-Conditioners On The Environment. A Case Study Of The Accra Metropolis /2014, The Year In Review
}

\author{
Michael Acquaye, S.O.B Oppong and L. Gyansah \\ Marine Engineering Department, Regional Maritime University \\ DOI: 10.29322/IJSRP.10.12.2020.p10821 \\ http://dx.doi.org/10.29322/IJSRP.10.12.2020.p10821
}

\begin{abstract}
This study sought to investigate the harmful effects of the processes of extraction of metals and other parts from used fridges, freezers and air-conditioners. The harmful effects such as the depletion of the ozone layer, pollution of water bodies, poisonous effects of lead, cadmium in infrared detectors, mercury in the thermostats batteries and switches among which are harmful on humans, water bodies and ozone layer.

To get the primary source of information on the topic, the views of 90 exporters and importers, 45 households, and 65 repair shop that deal in fridges, freezers and air conditioners in the Accra Metropolis were sampled. Although it was realized that importation of fridges, freezers and air conditioners generates employment for the populace and is a primary source of income generation, their activities of the extraction of parts of these used items have an adverse effect on the environment. It came out that most of the technicians that handle the repair works in the country do not know much about the dangers with the handling of refrigeration oils in $\mathrm{t}$
\end{abstract}

Index Terms- E-waste, ozone layer, imported fridges, air pollution and recycling

\section{INTRODUCTION}

$\mathrm{B}$ ackground of Study

This section deals with the e-waste as into the country and its effect on the environment in the Accra Metropolis. Electronic waste, commonly referred to as e-waste, is broken-down of old phones, computers, refrigerators, freezers, air conditioners, television sets, iPods, among others that have significantly diminished in usage value or no longer serve the purpose for which they were brought and are therefore discarded (Koranteng \& Darko, 2010; Puckett \& Smith, 2002).

Tiong (2013), defined e-waste used electronic equipment which are destined for reuse, resale, salvage, recycling or disposal. Kiransuan (2012), also defined it as re-usable (working and repairable electronics) and secondary scrap (copper, steel, plastic, etc.) to "commodities", and reserve the "waste" for residue or material which is dumped by the buyer rather than recycled, including residue from reuse and recycling operation. Similarly, Shinha (2004), defines e-waste as, an electrically powered appliance that no longer satisfies the current owner for its original purpose.

The emergence of the digital age has underscored the important role that the Electrical and Electronic Equipment "EEE "plays in the nation's socio-economic development, including education, health delivery and communication as well as global connectivity. All of these have led to a high rate of e-waste generation.

The environmental problems caused by the uncontrolled dumping and inappropriate recycling of electronic-waste have been a growing concern both globally and Ghana. The recent surge in sub-standard electronic and electrical appliances with their short life span has created a challenge especially in the management of waste that emanates from their usage. There is certainly awareness on environmental impact of wrong disposal of waste electrical and electronic equipment among the consumers, especially within Accra but due to lack of environmentally sound disposal options, most obsolete equipment are either given to the informal collectors or stored.

Hitherto, unknown to a lot of people is the delicate natural resource which is the underground water, which when polluted cannot be addressed. Since most of the scrap dealers dismantle their waste on the bare ground the chemical substances in them sip into the underground water thereby contaminating it. Some of the substances are also rained off into nearby water bodies such as ponds, rivers and lakes and the greater parts of the substances find their way into the seas.

\subsection{Statement of the problem}

The advent of technology advancement in the latter part of the century, has caught up with Ghana specifically in the early 1980 's, and currently generating a huge market in the areas of ewaste. The fastest growing type of waste stream is the electronic waste stream in the industrialized countries. This form of waste has grown almost three times faster than the overall municipal waste stream (UNEP Reports, 2005).

\subsection{The purpose of the study}

Dealing with e-waste disposal is of great concern to any nation. Unfortunately, some of these e-waste are dumped into the deep seas and most of them shipped to third world countries (including Ghana), who do not have the know how to dispose off 
this discarded items most of which have gotten to the end of their life span. This study will bring out the vulnerability the third world countries are exposed to and the need for governments to take the necessary precautions with special reference to Ghana which is the area of study.

It will serve as a source of reference for further research into the subject matter or related topics by interested persons.

\subsection{Objective of the study}

The main objective of the study was to find out if the disposal of used imported fridges, freezers and air conditioners have impact on the environment in general. The specific objectives of the study are to determine:

1. Ways of disposing used fridges and air conditioners in the Accra Metropolis.

2. Effect of disposals on the environment of Accra Metropolis.

3. Factors affecting the disposal of used fridges and air conditioners on the environment of Accra Metropolis.

\subsection{Research Question}

The study is guided by the following research questions:

1. Methods of disposing off e-waste in the Accra Metropolis?

2. What are the effects of disposed used fridges and air conditioners on the environment of Accra Metropolis?

3. What are the world's best practices of e-waste disposals?

\section{BRIEF REVIEW}

This entails a brief literature review on the history of importation of e-waste including used fridges, freezers and air conditioners into Ghana. Ways of disposing off used fridges and air conditioners and their effects on the environment. Factors affecting the disposal of used fridges, freezers and air conditioners on the environment and the health hazards they pose to humans.

\subsection{The History of E-Waste Importation}

It was scarce to see used imported used fridges, deep freezers on the local market over the years. Until the late 1980's, used imported fridges, freezers and air conditioners were not common on the local market. Before then, buying and selling of used imported fridges, freezers and air conditioners were not part of the major items sold on the Ghanaian market. These used fridges, freezers and air conditioners were imported into Ghana by seamen who worked with the then National Shipping Line, the Black Star Line.

Also, Ghanaians leaving in countries such as Germany and Italy also send these secondhand fridges and air conditioners down to their families in Ghana (Anane et al, 2011).

\subsubsection{E-Waste Imported into Ghana over a Period of 6 Years}

Used fridges, freezers and air conditioners are mainly imported from Europe and the North American. Though there is an insignificant local assembly of such equipment, brand new and used fridges, freezers and air conditioners are also imported into the country mainly from China and Dubai. According to AmoyawOsei et al (2011).

In the view of Frandsen et al, (2011) the Ghana Shippers Authority in 2011 stated that the country imported 31,400 metric tons of used electrical and electronic equipment including used fridges, freezers and air conditioners in the year 2010 alone, representing $74.6 \%$ increase as compared to the 2009 figure of 17,987 metric tons as shown in Figure 1.

2.1.2 Following the figures released for the year 2010 alone, the Port of Tema handled $72 \%$ of the total importation, which amounted to 23,623 metric tons, while the port of Takoradi cleared the remaining 7,768 metric tons, representing $28 \%$ of the total import.

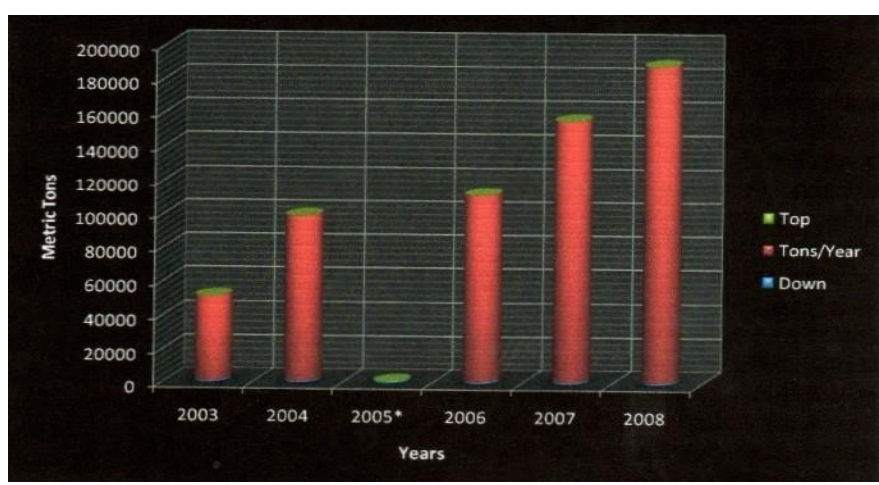

Figure 1. A chart showing the total quantity e-waste imported into Ghana over a period of 6 years

Source: UN Comrade (http://www. Omtracem.org/dBs/country 20058: no data available.

\subsection{Disposing off old fridges}

Butcher (2014), stated that CFC, Mercury, Polychlorinated Biphenyls (PCBs) and any other potentially toxic chemicals should not be discharged into the environment. Consumers should dispose off their old fridges appropriately. According to Butcher (2014), if one has not done so already, then he/she should call his or her local sales company to find out if they can offer a trade-inprogram.

\subsection{Effect of Disposed Used -Fridges, Freezers and Air Conditioners on the Environment}

Refrigerators, freezers, dehumidifiers and air conditioners contain chemicals such as refrigerants and insulation that releases ozone-depleting substances into the atmosphere when they are thrown away, older models can even contain mercury and Polychlorinated biphenyls (PCBs). Federal laws require proper removal and disposal of refrigerants to reduce the possible effects of these chemicals (Frazier, 2003).

\subsection{Electronic Waste Dump of the world}

For Agbogbloshie dumping site in Accra-Ghana to be mentioned alongside Guiyu in China as one of the world's dumping sites, shows how serious the e-waste menace is in Ghana. Agbogbloshie is said to have a dumping site where electronic waste is burnt and disassembled with no safety or environmental 
consideration (Bridgend et al, 2008). The e-waste recycling industry in Ghana is widely associated with severe health and safety risks for workers involved in the sector. These risks emerge primarily due to improper and crude recycling techniques used for the recovery of raw materials, such as, open incineration of cables and wires to recover copper. Low grade printed wiring boards are incinerated to reduce the e-waste volumes. Insulating foam, primarily polyurethane (PUR), from obsolete refrigerators and automobiles tires, are used as co-fuels to sustain the fires used for burning the waste (Ross, 2011).

Guiyu in the Shantou region of China is said to have a huge electronic waste processing area. It is often referred to as the "ewaste capital of the world" (Bridgend et al, 2005). The city employs over 150,000 e-waste workers that work to disassemble old computers and recapturing whatever metal and parts they can reuse or sell. Uncontrolled burning, disassembling, and disposal cause a variety of environmental problems such as ground water contamination, atmospheric pollution or even water pollution either by immediate discharge or due to surface run off (especially near coastal areas), as well as health problems including occupational safety and health effects among those directly and indirectly involved due to the methods of processing the waste.

According to Huo et al, (2007), limited investigations have been carried out on the health effects of Guiyu's poisoned environment. One of them was carried out by the Shantou University Medical College. The test was carried out on 165 children for concentration of lead in their blood. $85 \%$ of the children in Guiyu had lead in their blood more than 100. Anything above that figure is considered unsafe by international health experts. However the average reading for the group was 149. High level of lead in young children's blood can impact on their intelligent quotient and the development of their central nervous systems. The highest concentrations of lead were found in the children of parents whose workshop dealt with circuit boards and the lowest was among those who recycled plastic.

The nature and extent of chemical contamination found at the sites in Ghana is similar to that found at e-waste open burning site in China, India and Russia (Bridgend et al, 2008). In some countries, studies have found contamination of wider environment around e-waste recycling workers homes. The environmental contamination found in Ghanaian samples, suggest children working on and living near e-waste sites could be exposed to toxic chemicals (Bridgend et al, 2008).

Greenpeace experts collected soil sediment samples from two e-waste recycling sites; Agbogbloshie scrap market in Accra and also from Koforidua. The samples were analyzed at the Greenpeace Research Laboratories at the University of Exeter, United Kingdom. The study found that many samples contained numerous hazardous substances including very high levels of the toxic metal lead; chemicals such as phthalates, which are known to interfere with sexual reproduction; and chlorinated dioxin known to promote cancer (Bridgend et al, 2008).

\subsubsection{Effects of E-Waste on the Soil}

The recycling activities at Ghanaian scrap yards include mainly dismantling, uncontrolled dumping as well as pyrolytical processes. With reference to Bridgend et al (2008), hydrolytically process such as leaching precious metals from printed wiring boards was not observed.
The recycling activities at numerous small workshops within the scrap yard often take place directly on unfortified grounds. Harmful substances released during dismantling therefore leaks directly into the soil. Within the burning areas, scrap yard workers use numerous temporary fires to burn plastics, mainly from copper cables and wires as well as television casings.

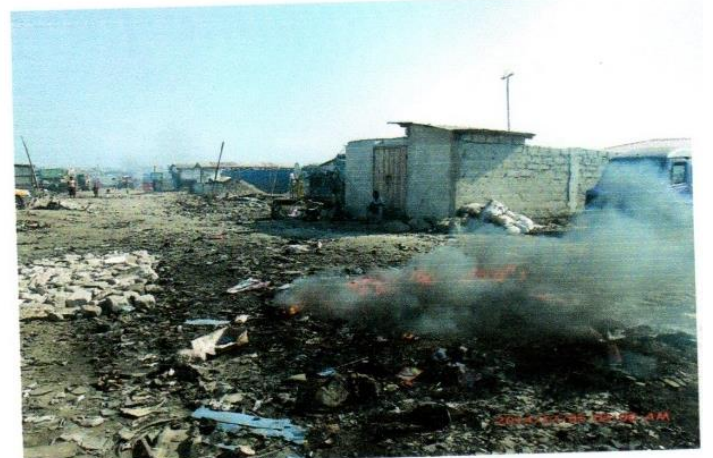

Figure.2 smoke from a burning electrical cable at Agbogbloshie Scrap Yard

Source: Researcher's Field Trip

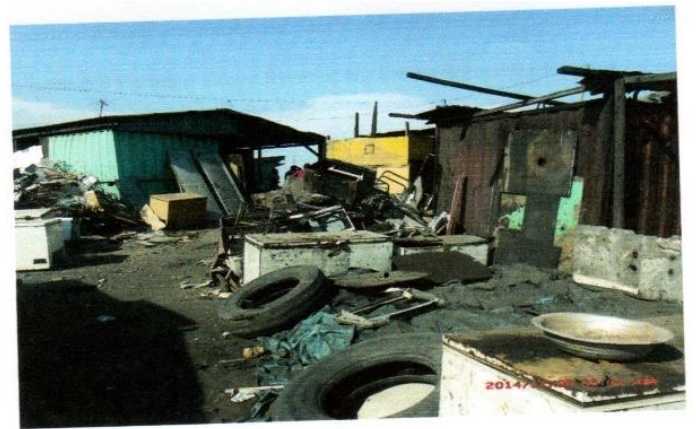

Figure 3 Scraps at Galloway Scrap Yard. Source: Researcher's Field Trip. Source: Researcher's Field Trip

\subsubsection{Effects of Oil on the Soil}

According to Patrick (2007), Oil spills that make their way into groundwater can have devastating effects that linger for many years. When people think of oil spills, they often think of spill in the ocean. However, the spills that cannot be seen are often the most costly and difficult to address. Clean groundwater is a delicate natural resource; a serious oil spill can poison that resource in an instant. Cutting open fridges, freezers and air conditioners compressors spills oil on the ground at the scrap yards. 


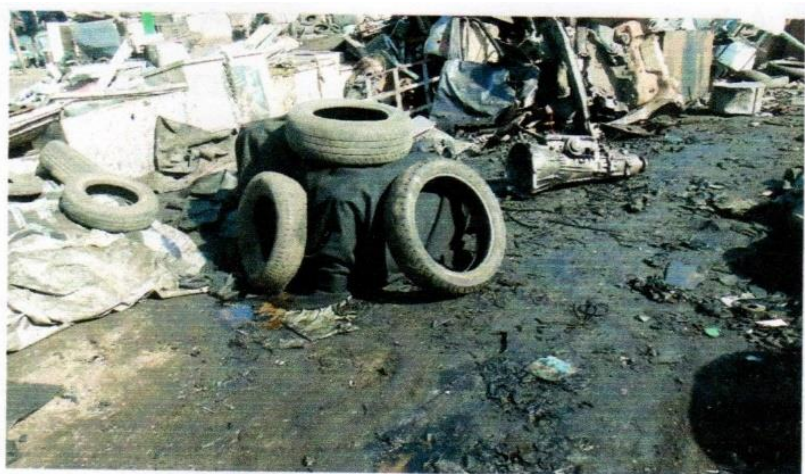

Fig 4 oil spill at Agbogloshie scrap yard Source: authors field survey (2014/12/05)

\subsubsection{Effect of E-waste on the Water Bodies}

The heavy metals and organic substances released to the soil and the surface water lead to high pressure on the ecosystem. The Odaw River in Ghana used to be an important fishing ground for the neighboring communities. Since the waste electrical and electronic equipment's recycling activities started about ten (10) years ago, the river has become dead. Due to the burning and dumping activities, most of the vegetation has disappeared (Amoyaw-Osei et al, 2010).

\section{Methodology}

The methods and techniques employed by the researcher to obtain data for the study consists of methods of the population and sample size, sampling technique, data collection, data collection instruments, field experiences and methods of data analysis. Earlier in the research proposal it was indicated that major part of the study will be carried on at Agbogbloshie Scrap yard and other smaller scrap yards in Accra and its surrounding areas.

\subsection{Research Design}

The research design adopted by the researcher was descriptive research design. Descriptive research design refers to a research which specified the nature of a given phenomenon. It determines and reports the way things are done. Descriptive research thus involves collecting data in order to test hypothesis or answer research questions concerning the current status of the subject of the study. According to Allen et al, (2001) descriptive research seeks to portray accurately the characteristics of a population. The findings also maintain that in descriptive research, accurate description of activities, objects, processes and persons is the objective.

Descriptive survey was used because it specifies the nature of a given phenomenon and reports things the way they are. In this study the researcher does not manipulate variables, data collected under natural settings to answer the research questions which were geared towards determining the status quo of sociological and psychological variables as they occur in natural settings. Also, the descriptive survey is used because condition and events already exist and there is no intervention in terms of treatment to experimental groups.

Moreover, variables and procedures are described as accurately and completely as possible in descriptive survey designs. A descriptive survey involves asking the same set of questions often prepared in written questionnaire to a large number of individuals. Thus, descriptive survey is directed at determining the nature of a situation as it exists at the time of study. It helps identify conditions presets and points out future needs. Surveys also provide a lot of information from a large sample of individuals from which generalization could be made about the population. A descriptive research study was used for the study because it presents information systematically on evaluation the impact of used imported fridges, freezers and air conditions on the environment in Accra Metropolis.

\subsection{Data Collection Instruments}

The instrument used in collecting the data for the study are questionnaires, observations and interviews. The questionnaires and interviews were employed because different opinions and suggestions which were necessary to obtain first-hand information about the study area were needed.

\subsubsection{Target Population}

Agbogbloshie being the largest scrap yard in the country was the target area where most of the studies on scrap dealers were carried out. Other areas where some data was obtained on scrap dealers are Galloway, Ashaiman and Kokompe, all in the Greater Accra Region. The study also targeted importers and dealers of fridges, freezers and air conditioners as well as households where items end and exit from.

\subsubsection{Sampling Technique}

Simple Random Sampling was used at the location level to randomly sample from the demarcated location within the scrap yard that gave the various categories: repaires, importers/dealers and households within the Accra metropolis.

\subsection{Profile of Agbogbloshie}

Agbogbloshie, a suburb of Accra, is known as a destination for exploitation and environmental dumping of electronic waste (e-waste) from industrialized nations. The site covers approximately four acres and is situated on the banks of Korle Lagoon; northwest of Accra's Central Business District. About forty thousand Ghanaians inhabit the area, most of whom are migrants from rural areas. Due to its harsh living conditions and rampant crime wave, the area is nicknamed "Sodom and Gomorrah".

The Agbogbloshie site started as a food stuff market for onions and yams. Over the years it has grown into a slum with people dealing in all kinds of scrap, and a dumping ground for old electrical and electronic products and household waste. The scrap yard has grown steadily into a popular recycling area, where old and discarded Electrical and Electronics Equipments (EEE) could be put to use. Hundreds of tons of e-waste end up there every month as final resting place, where they are broken apart to salvage copper and other metallic components that can be sold.

The scrap dealers discovering the place as good location for business started to erect temporary stalls and sheds for their wares and activities. The dealers later registered with the National Youth Council as the Scrap Dealers' Association of Ghana, and the land was leased to them in 1994. To date, Agbogbloshie has become the hub for informal "recycling" industry in Ghana. Besides this main scrap yard, there are other smaller known scrap yards as 
Galloway, Kokompe and Ashaiman in the Greater Accra Region. Other much smaller scrap yards keep springing up throughout Accra. (Amoyaw-Osei et al, 2011).

Figure 5 and 6 shows the aerial view of Agbogbloshie Scrap yard and market area

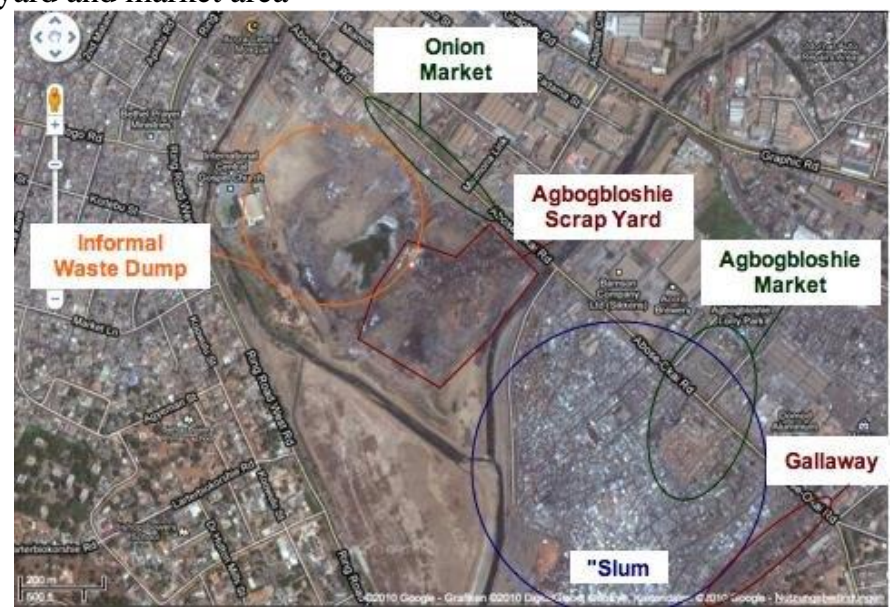

Figure 5 The Agbogbloshie area

(Source: Google maps)

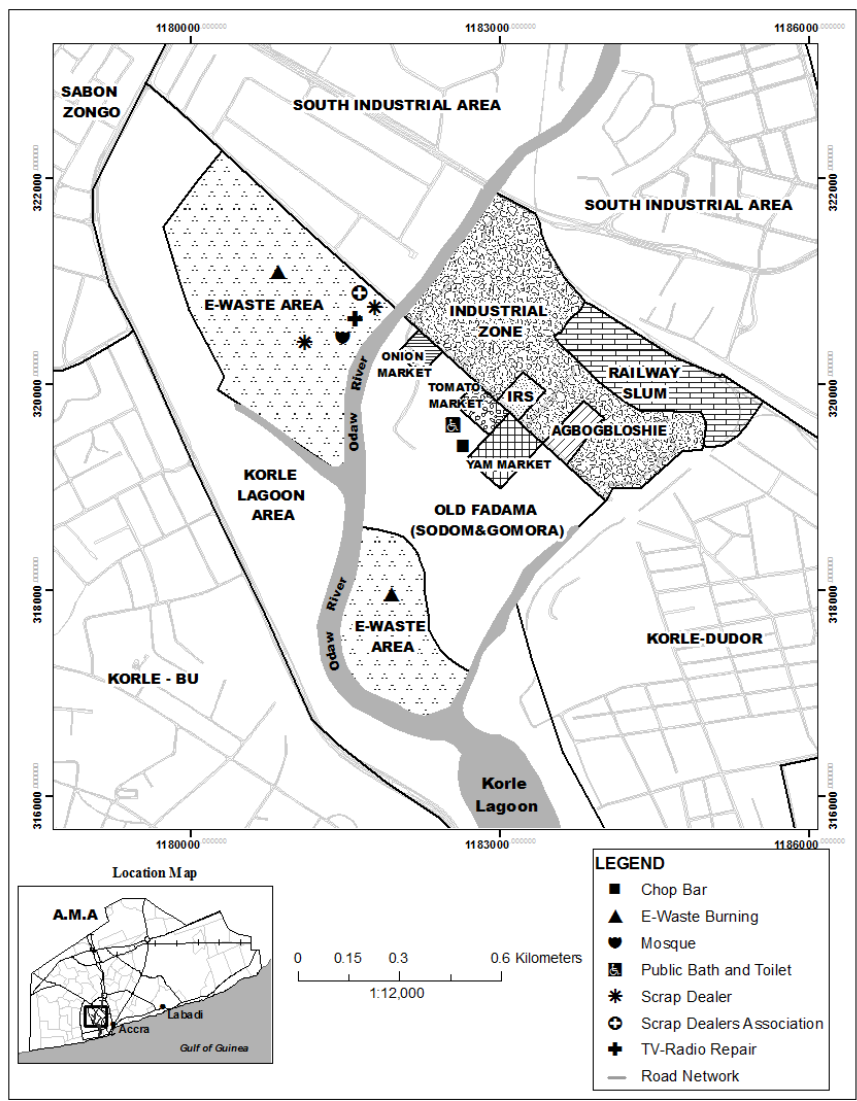

Figure 6 The Agbogbloshie scrap yard (Source: qamp.net)

\subsection{Sampling of Households}

Households within the sample areas in the Accra metropolis were selected to participate in the study using simple random sampling technique. The reason for selecting households to participate in the study is due to high number of used fridges, freezers and air conditioners sold in the Accra Metropolis.

A preliminary study was done in the Accra Metropolis to map out areas that the study was conducted. This was done with the consideration of socio-economic life style of the people. Targeted sampling was used to find the areas that the study was conducted. In each area where necessary, a number of households were identified and each household was marked. Then using simple random sampling technique, one person in the household was selected for the study.

\subsection{Sampling of Repair Workshops}

A study was conducted to find workshops that the study was conducted and this was by observation. It was observed that apart from large workshops that repair fridges, freezers and air conditioners, there were mechanics that do not have workshops but work in small wooden structures along the roads in Accra. Besides this, there were others too who work on fridges and freezers in car body work workshops. Based on this, the $37.5 \%$ share of the sample size 200 was given to the Repair Workshop.

\subsection{Sampling Importers and Dealers}

In the area of importers targeted, sampling was used as most of them can be found at the Tema Port. When it came to selecting the respondents for the studies, simple random sampling was used at the port area. Other importers were also picked at other areas in Accra where used fridges, freezers and air conditioners were sold. Available sampling technique was used in selecting the dealers in Accra metropolis. This was done by observing areas that have high concentration of fridges and air conditioners. Sellers were also targeted for the study.

\subsection{Data Collection Method}

The instrument used in collecting information from respondents was the questionnaire. And the method adopted was self-administered face-to-face questionnaires. Respondents who could read and write were given the questionnaires to respond to by themselves and those who could not were guided but not directed by the researcher or his trained research assistant to respond to the questionnaire.

The quantitative data drawn from the study was analyzed with the aid of Statistical Package for Social Sciences (SPSS) version 16. Having pre-coded all the categories on the questionnaire, the quantitative data was then input into the computer on Microsoft Excel. After this the data was moved on the Statistical Package for Social Sciences (SPSS) which helped in the determination of percentages, chi-square analysis, p-value analysis and charts with tabulation that were used to study the relationship between two or more variables.

As stated earlier, the questions were both close-ended and open-ended and structured in such a manner as to make it easy for respondents to understand. The use of close-ended questions were also aimed at yielding the quantitative data required and for the easy understanding of the research once the questionnaires were returned hence the researcher ensured that all possible categories of the responses were included for respondents to answer. The open-minded questions gave respondents the opportunity to give further explanation to the questions other than the "yes/no" answers provided. 


\subsection{Field Experience}

Field trips were paid to the scrap yards at Agbogbloshie, Galloway, Ashaiman and Kokompe. This enabled access to firsthand information on scrap dealers and activities. Similar visits were paid to the repairers and importers of used fridges, freezers and air conditioners together with used e-waste shops. Some visits were paid to the Tema Port (main harbour) to ascertain operation and possibility of observing the presence of end-of-life fridges, freezers and air conditioners where they are transported straight to scrap yard on arrival. Visits were also paid to land filling sites to see the recycling practices undertaken there.

\subsection{Selections of Respondents}

Respondents for the study were selected by stratified sampling technique. This technique was applied because of the different areas that the study was handling and the different characteristics which were likely to impact on the research. This required that each group should be represented in their right percentages.

Data was collected from repairers, dealers and importers and households. Since the study cannot capture responses from all over the Accra Metropolis targeted sampling was used in some cases and in others random sampling was used.

\subsubsection{Sample Size}

A total number of two hundred (200) respondents are expected to be involved in the study. Repair workshops, importers/dealers and households were captured, but majority were the importers/dealers with the following distribution:

Table 1 shows the target population, sampling technique and sample size.

\begin{tabular}{|l|l|l|l|}
\hline IDENTITY & $\begin{array}{l}\text { TARGET } \\
\text { POPULATION }\end{array}$ & $\begin{array}{l}\text { SAMPLING } \\
\text { TECHNIQUE }\end{array}$ & $\begin{array}{l}\text { SAMPLE } \\
\text { SIZE }\end{array}$ \\
\hline Repairers & 200 & $\begin{array}{l}\text { Simple } \\
\text { Random }\end{array}$ & 65 \\
\hline $\begin{array}{l}\text { Importers } \\
\text { and Dealers }\end{array}$ & 300 & $\begin{array}{l}\text { Simple } \\
\text { Random }\end{array}$ & 90 \\
\hline Households & 105 & $\begin{array}{l}\text { Simple } \\
\text { Random }\end{array}$ & 45 \\
\hline TOTAL & 605 & & 200 \\
\hline
\end{tabular}

Source: Authors Field Survey (2014/12/05)

\section{PResentation AND ANALYSIS OF FInDINGS}

This section presents the outcome of the research which includes analysis of data obtained from the field which was collected mainly through the administering of questionnaires and observations. It describes the views and opinions of stake holders including 45 Repairers 77 Importers/Dealers and 36 Households within the Accra Metropolis who took part in the study about how the effects of improper disposal of discarded used imported fridges, freezers and air conditioners and the hazards on humans and the environment with particular reference to Abogbloshie, Ashaiman, Galloway and Kokompe suburbs of Accra, Ghana. In all, two hundred (200) questionnaires were administered to the target groups. However, 158 questionnaires were received representing $78 \%$ of the total questionnaires distributed.

\subsection{Gender Distribution}

Figure 4.1 shows the ratio of male to female respondents within the company of which the males dominate with $66.67 \%$. The remaining percentage, $33.33 \%$, represents the females. Relatively, the ratio of male to female respondents sampled under the category of repairers also indicates that the males dominate with $76.67 \%$ whilst the females represent $33.3 \%$. For the sampled respondents for importers/dealers the males represent $92.21 \%$ of the total sample whilst the females represent $7.79 \%$ of the total sample. This ratio of respondents was obtained due to the females unwillingness to participate in the survey despite the fact that in Ghana, there is a higher percentage of women as compared to men which is 0.98 male/ 1 female (CIA World Fact book, 2013)

\subsection{Current Situation of Imported Used Electronics 4.2.1 Location of Importers}

Figure 7 shows the location of importers/dealers of used fridges, freezers and air conditioners. Majority (about 47\%) of the sampled respondents have their business located at Tema, Nungua, Kaneshie. About $24 \%$ of the dealers are located in Galloway, a suburb of Accra whilst 21\% are in Agblogbloshie. Dealers sampled in Ashiaman as their business location constituted only $8 \%$.

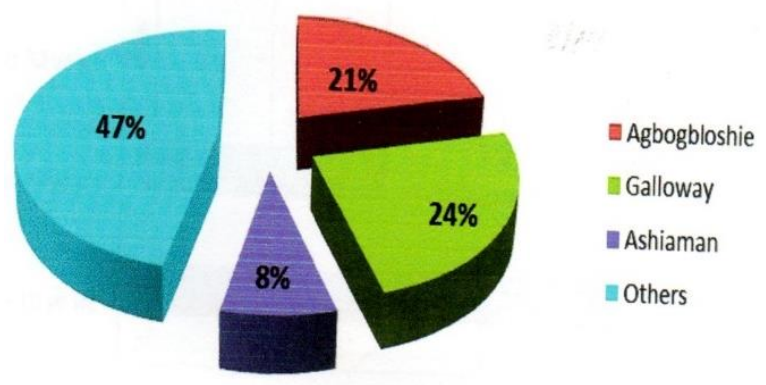

Figure 7. Business Location of importers/Dealers Source: Author's field survey (2014/12/05)

4.2.2 Knowledge of Environmental Legislation on the Importation of Used Fridges, Freezers and Air conditioners

When asked about any knowledge of environmental legislation in Ghana on the importation of used fridges, freezers and air conditioners, about $69.4 \%$ of importers/dealers indicated that they know of the existence of an environmental legislation on used electronics whilst about $30.6 \%$ of the sampled importers said they did not know about any environmental legislation on importation of used fridges, freezers and air conditioners. These importers $(69.4 \%)$ also stated that they are aware of the environmental hazards caused by used electronics. About $56.4 \%$ of the importers indicated their awareness of a special treatment of 
used fridges, freezers and air conditioners for safe disposal whilst $43.6 \%$ indicated no awareness of such special treatment.

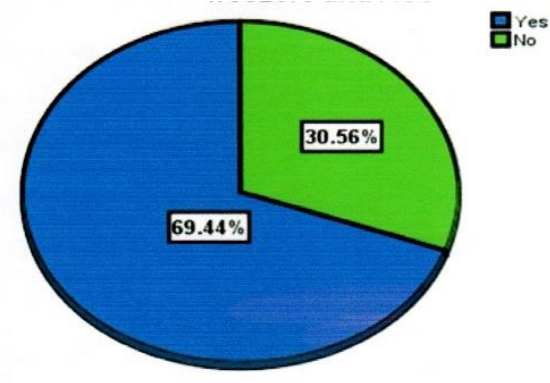

Figure 8. Awareness of disposal substance in fridges, freezers and ACs.

Source: Author's field survey (2014/12/05)

\subsubsection{Health and Safety}

About $92 \%$ of importers disagreed that the used fridges, freezers and air conditioners are hazardous to people's health whilst $8 \%$ agreed that it is hazardous to their health. Whilst $72 \%$ of importers agreed that the working conditions of used electronics are safe, $28 \%$ were of the opinion that they are in good conditions and are safe to use although they are aware of the environmental hazards the electronics are likely to cause when disposed off. About $68 \%$ of the respondents were not aware that some hazardous fractions in fridges, freezers and air conditioners need special treatment in order to be safely disposed off. They are also not aware of what happens to the equipment when they are disposed off.

\section{DISCUSSION OF RESULTS}

This section addresses significant findings that were identified during the analysis of the data. The discussion highlights the major findings of the research and inferences made.

\subsection{Ways of Disposing Used Fridges, Freezers and Air Conditioners in Accra}

For a safe disposal of used fridges, freezers and air conditioners which contain CFCs or HFC, the need to dispose them off appropriately is indispensable. Furthermore, other fractions of concern (mercury switches, PCB-containing capacitors, ammonia, chrome-VI and cable-insulations) have to be taken care of.

The results of the study showed that $97 \%$ of repairers, importers and households would opt for the unwanted e-waste to be picked from their houses and locations of their shops for disposal. These respondents also indicated that they are not willing to pay for the disposal or recycling of the used equipment. This implies that although there is an immense benefit to recycling and the safe disposal of e-waste, respondents are not willing to pay heed to this action. This action is likely to impose hazards to the environment because collection of the refrigerators that has to be transported to dedicated recycling facilities may cause the used equipment to damage its cooling circuit causing CFCs or HFC emissions. (Prakash \& Manhart, 2010).

\subsection{The Socio-Economic Effects of Disposed Used Fridges and Air Conditioners on the Environment of Accra}

This ratio of respondents obtained for the study was due to the females unwillingness to participate in the survey despite the fact that in Ghana, there is a higher percentage of women as compared to men which is 0.98 male/ 1 female (CIA World Fact book, 2013). The median age of respondents implies dealers/importers, repairers as well as household members who sell used fridges, freezers and air conditioners are within the active/youthful age. This also implies that most importers/dealers, repairers and households have families to cater for. Inferences from the results suggest that the business of used fridges, freezers and air conditioners generate employment for them and thus is the primary income activity for them. The income generated from this business implies that it can cater for the basic needs of importers and repairers.

Used refrigerators, freezers and air conditioners disposed off have to undergo special hazardous waste disposal. For the subsequent degassing of the cooling circuit, the refrigerator has to be lifted and tilted. The cooling circuit is then evacuated using negative pressure. The oil-refrigerant mixture is collected in a tank and treated thermally to separate the refrigerants (Prakash \& Manhart, 2010).

\subsection{The Factors Affecting the Disposal of Used Fridges and Air Conditioners on the Environment of Accra}

The impact of used fridges and air conditioners on the environment of Accra is increasing. The ways of disposing used fridges and air conditioners in Accra, the socioeconomic effects of disposed used fridges and air conditioners on the environment of Accra and the factors affecting the disposal of used fridges and air conditioners on the environment of Accra.

The educational level of respondents may imply that the users and dealers of e-waste in the study area have attained at least the basic level of education to understand the industry they operate in. This implies that the awareness of recycling of e-waste has a dependence on their educational level.

The business of importation of used electronics may be defined as small scale with reference to the number of employees only as the basis for categorizing the business.

Reasons given by the importers for the reduction in the quantities of imported used electronics include a ban on the importation of the goods and the economic hardship in the country. This clearly indicates that the importation of fridges, freezers and air conditioners are done on a regular basis but with a reduction in the quantities of importation.

This implies that there exists an environmental legislation on the importation of used electronics of which importers of used fridges, freezers and air conditioners know of.

Further implications also show that importers are aware of the environmental hazards caused by e-waste and are also aware of a special treatment to these used electronics safe disposal. With no records/inventory on quantities of fridges, freezers and conditioners stores or discarded, importers may not see the need for developing procedure which will guide them in disposing off the unwanted electronics. 


\section{CONCLUSION AND RECOMMENDATION}

It can be concluded that;

1. The importation of fridges, freezers and air conditioners generates employment for the youthful population and are primary source of income generation.

2. The activities of the importation of these used electronics have an adverse effect on the environment and awareness creation of this implication and a recycling plant will contribute to the transformation of the handling of ewaste in general in Ghana.

3. A report in the dailies indicated that the e-waste plant at the scrapyard at Abogbloshie is standing idle and should therefore be put to use so that electrical cables that are burnt to extract the copper wires and the emission of smoke into the atmosphere would minimize if not stopped.

4. The scrap dealers should be trained •to enhance their capacity to handle the used fridges, freezers and air conditioners and other electrical waste. This is due to the fact that the refrigeration and air conditioning plant either big or small contain some form of gas that have to be handled carefully and not expelled in to the atmosphere. Repairers and others who handle refrigerants, such as reclaiming, recovery and recycling of refrigerants.

Following this study, it is recommended that:

Awareness creation sessions must be organized on e-waste and its importance to the environment when recycled is of positive benefit to the environment. This will ensure that households, repairers and importers/dealers understand the need of recycling of discarded e-waste. Government institutions and other agencies such as the Environmental Protection Agency, Civil Society Organizations and Non-Governmental Organizations have their capacity built in the recycling of e-waste. A remuneration scheme should also be instituted to create a sense of belonging in ensuring the safety of the environment.

There should be an establishment of a recycling plant for ewaste in Ghana with a well-coordinated waste collection mechanism that will operate at the community level to ensure that discarded fridges, freezers and air conditioners are well disposed off. In so doing, jobs are created for scrap dealers and other sections of the population.

Stakeholders play a major role in propagating a clean environment. It is thus recommended that stakeholders such as community leaders and unit committees in the various host communities of the company be duly and adequately informed and their capacity built on e-waste and its effect on the environment.

\section{ACKNOWLEDGMENT}

First and foremost, our sincere thanks goes to the Almighty God for a successful research work. We appreciate the help from Agbenyega Caleb Yao in helping compile this work.

\section{REFERENCES}

[1] Amoyaw-Osei et al. (2011). Ghana E-Waste Country Assessment. www.greenadgh.com/misc- files/assessement.pof9/17/2013.
[2] Althows A. et al (1997). Modern Refrigeration andAir Conditioning, Illinois, The Goodheart-Willeox Company Inc, Tinle Part

[3] Anan-thanarayanan (2006), Basic Refrigeration and Air Condition, New Dehli, Tata McGraw-Hill, Publishing Company Limited.

[4] Amalalo D. (2013). Montreal Protocol Implementation in Ghana, Accra Environmental Protection Agency.

[5] Butcher A., (2014). Disposing off Old Fridges. www.about.com.

[6] Ban Ki-Moon (2014). International Dayfor the preservation of the ozone layer. http//Montreal-protocol.org/en/informational.php. 10/27/2014

[7] Brigden et al (2008), Chemical contamination at e-waste recycling and disposal sites in Accra and Koforidua, Ghana, Greenpeace International, Amsterdam.

[8] Constantine, S., Denver, A., Hakim, S. et al (1999). Ghana Residential Energy Use and Appliance Ownership Survey Berkereley National Laboratory. University of California Berkereley, CA 94720.

[9] Cope, T. (2011 Disposing of old fridges and Freezers. http//www.defa.gev.uk.

[10] Clark R.B. (2007). Marine Pollution, Oxford, Oxford University Press Great Clarendon Street

[11] CIA2013, U.S Central Intelligence Agency, The World Fact Book 2013 www.cia.gox/library/publication/the-world-factbook/geos/gh.html $17 / 12 / 2014$

[12] Easton and MacConkey (1993). Applied Thermodynamics, Harlow, Pearson Education limited Essex CM202JE

Frandsen, D. M., Rasmussen, J \&Swart, M. U. (2011). What A Waste. Dan Watch,Noerregade 15, 5, 1165 Copenhagen K Denmark

[13] Frazier K. (2003). Ways of Disposing used air conditioners and fridges, E-waste Management Corp-US

[14] Grossman, E. (2011) Environmental Health Impacts of E-waste. High Tech Trash.http//www.defra.gev.uk

[15] Haefliger, P., Mathieu-Nolf, M., Lociciro, S. et al (2010). Mass Lead Intoxication fromInformal Use Lead Acid Battery in Darkar, Senegal. Environmental

[16] Health Prospective, vol. 117(10), 2009, p 1535-15

[17] Ilellstrom, L., Elinder, C.G., Dahlberg, B. (2001). Cadium Exposure EndStage Renal Disease herican Journal ofKidney Diseases, 38(5) p] 001-1008 Holst, H., Minimierung, V.K., (2008). Entosorgung von Elektronikschrott Co.

[18] Proceedings of the 21. Aachener Kolloquium Abfallwirtschaft 2008.

[19] Home, R.E. \& Gersakis J. (2006). Literature Review on the Environmental andHealth Impact of Waste Electrical and Electronic Equipment, (WEEE), RMIT University, Centre for Design.

[20] Huo et al (2007), E-Waste nightmare, Guiju, Elevated Blood Lead levels of Children in Guiju. www.greenpeace.org/eastasia/campaings/toxics/problem/ e- waste/guiju.

[21] Johri et al (2008). E-Waste, New Dehli, Implications, regulations and management in India and current global best practices. The Energy and Resources Institute Press.

[22] Kuper, J., \& Hojsik, M. (2008). Greenpeace. Poisoning the Poor- Electronic Waste in Ghana. Amsterdam.

[23] Kimthong (2011), Health Impact of E-Waste Repacking, US Environmental

[24] Protection Agency Stratospheric Protection Division (6x05H) EPA-430-F11-06

[25] Koranteng S.S. \& Darko D.A. (2011). ' 'The E-waste Menace in Ghana " Institute of Environmental and Sanitation Studies Accra, University of Ghana.

[26] Kuriyama, S.N., Talsness, C.E., Grote, K. et al (2005). Development Exposure to Low-dose PBDE-99 effect on male fertility and neurobehavioral in rat offspring. Environmental Health Protective, Vol. 113, p. 143-154

[27] Kurt C. (1993), Thermodynamics and heat power, New York, Macmillan Publishing Company, 113 Sylvan Avenue.

[28] Kifurmi RS \& Gupta J.K. (2001), Refrigeration and Air Conditioning, New Dehli, Rajendra Ravindra Printers Ltd.

[29] Miller R \& Miller M. (2012). Air Condition and Refrigeration, New York, McGraw-Hill.

[30] Miffin (2014). Disposing off Fridges, www. fresppiance.com. 
[31] Prasad M. (2003). Refrigeration and Air Condition, New Dehli, New Age International Publishers Ltd.

[32] Rajput R. K. (2012) Refrigeration and Air Conditioning, New Delhi, S.K. Kataria \& Son

[33] Rogers \& Mayheew (1992), Engineering Thermodynamics, Harlow, Edinburgh Gate, Pearson Education Limited, Essex CM202JE.

[34] Swain, E. (2007). Recycling impact on the U.S. Environment, Environmental Protection Agency. Stratospheric protection Division, EPA - 430-F-11-06. www.epa.gov.

[35] Sapali S.N. (2011). Refrigeration and Air Conditioning New Dehli, Asoke K. Ghosn PHI Learning

[36] Siddarth, P. \& Andreas, M. (2010). "Socio-Economic Assessment and Feasibility Study on Sustainable E-waste Management in Ghana OkoInstitute e.v. Freiburg Germany.

[37] UNEP (2005): " e-waste, the hidden side of IT equipment 's manufacturing and use Early Warnings on Emerging Environmental Threats No.5 United Nations Environmental Programmed.

[38] Whiteman \& William (1992). Refrigeration and Air Condition Technology New York. Delmar Publishers Inc. Columbia Circle.

[39] www.brudirect.com/7726-recycling-wastematerial

[40] www.studymode.com/essays/electronic-waste-1252477.html

[41] www.projectren.org/ecmu.php

[42] www.content.time.com/time/photogallery/0.29307, 1870162,00.htm
[43] www.basel.int. /e-wasteAfricaproject sustainable waster Electrical Electronic Equipment Recycling in Ghana/John A Pwanang (Director, Chemical control and management environmental protection agency, Accra Ghana) ww.ehow.com/info-8340752-effect-oil-spills-ground-water.html.

[44] ww.livestrong.com/article/159954-fact-about-landfill-styrofoam.

\section{AUTHORS}

First Author - Michael Acquaye, M.Tech Mechanical Engineering, 1st Class Refrigeration Engineer, Marine Engineering Department, Regional Maritime University Box 1115, Nungua, Ghana, Tel: +233(0)249460358 Email: michaelappiahacquaye@gmail.com

Second Author - S.O.B Oppong, PhD Chemistry / Nano Science and Materials, Marine Engineering Department, Regional Maritime University, Box 1115, Nungua, Ghana Tel: +233(0)548731928 Email: samuel.oppong@rmu.edu.gh Third Author - L. Gyansah, PhD in Materials Science and Engineering, Mechanical Behaviour and Engineering applications, Marine Engineering Department, Regional Maritime University, Box 1115, Nungua, Ghana Tel: +233(0)552032439 Email: gyansahaclass@yahoo.com 